seen them as quiet and prosperous. They now appear threatened from without by their barbarian neighbors and plagued within by various troubles. including (according to Pippidi, p. 132) social unrest. The Geto-Dacian kingdoms, on the other hand, now seem more impressive, particularly the empire of Burebista who, a recently discovered inscription confirms, destroyed Histria as well as other Pontic cities in the first century B.C.

Some of Pippidi's views have been questioned-for example, his support of the Eusebian date (657-656 B.c.) for the founding of Histria, or of the era of Lysimachus for that city's fourth century destruction layer. That so few of his conclusions have been successfully challenged, however, suggests the extent to which Pippidi dominates the field. This book will remain the standard for many years. Hopefully, there will be future editions to take account of new discoveries.

RICHARD A. TODD

Wichita State University

\title{
MODERNIZATION IN ROMANIA SINCE WORLD WAR II. By Trond Gilberg. New York: Praeger Publishers, 1975. xiv, 261 pp. Tables.
}

Trond Gilberg's volume on modernization in Rumania is a masterful study. The author, after defining the variables of the concept of "modernization," focuses his analysis on testing the validity of Nicolae Ceausescu's theory, and practice, of modernization culminating in the attainment of the "multilaterally developed society."

The main body of the text consists of a well-argued and amply documented review of Rumanian achievements in the process of modernization. The topics discussed range from the character and effectiveness of the work of the agents of modernization, that is, the Communist Party and its affiliated organizations, to progress in such areas of modernization as education, industrialization, agriculture, communication and social services, and integration of ethnic minorities. The author's conclusions support the contentions of the Rumanian leadership regarding the inexorable progress of modernization and the inevitable achievement of a multilaterally developed society in Communist Rumania upon realization of the goals of the regime.

Gilberg's arguments are plausible, supported by the high quality of his data and analysis. Plausibility, however, is not synonymous with accuracy. At least two of Gilberg's basic premises are questionable. First, the author's appraisal of the relative degrees of development in pre-Communist and in Communist Rumania seems too heavily weighted in favor of the Communist. Second, and perhaps more fundamental, Gilberg's assessment of the aims and motivations of the rulers of contemporary Rumania seems distorted. Granted that Rumania was underdeveloped at the end of World War II, and that Ceausescu and his associates are committed to modernization, it may be clained that Rumania in 1975 is only relatively, if not marginally, more modern than it was in 1945. Whereas this contention may be challenged in terms of comparative levels of industrial production, agricultural development, and socioeconomic services, it probably cannot be refuted in terms of advances in the political mentality of the leadership and of the relative proficiency of the technological, scientific, and cultural personnel concerned with moderniza- 
tion. Gilberg recognizes this dilemma but propounds the optimistic solution that the forces of modernization will eventually overcome those of retardation. $\mathrm{He}$ may be correct in his judgments and predictions but the evidence, as of 1975, cannot rule out less optimistic assessments and prognoses.

Stephen Fischer-Galati

University of Colorado

ROMANIA'S SOCIALIST ECONOMY: AN INTRODUCTION TO A CON-
TEMPORARY EXPERIENCE OF ECONOMIC DEVELOPMENT. By Costin Murgescu. Translated from the Rumanian by Leon Jaeger. Bucharest: Meridiane Publishing House, 1974. 178 pp. Paper.

This is a book which should not be taken very seriously by scholars interested in East European economies, central planning, or comparative systems. It would not even serve as a decent supplementary text for students in a course. Aside from the fact that the syntax is turgid and the style dull, the translation is so poor in some spots that it is impossible to determine the meaning of a particular sentence.

The book's major virtue is that it makes a good deal of recent data available to the English-speaking world. Contemporary economic performance is compared with pre-1945 achievements and this is useful, but there is no effort to evaluate the structural change which has taken place. Indeed, the book suffers from a liberal sprinkling of political rhetoric-in particular, quotes from Ceausescu's speeches.

Regrettably, there is a virtual absence of thoughtful economic analysis in this volume. We are asked to accept such meaningless assertions as the national plan "ensures the accomplishment of the Programme of the Romanian Communist Party, in accord with the objective laws of historical development and with the specific realities of each phase" (p. 71).

The greatest disappointment, however, is that a book written so recently does not at all deal with econonic reform. While the book concentrates on macro structural issues and accomplishments, an uninformed reader night well be left with the impression that nothing has happened in Rumania since the Soviet Union taught the Rumanians central planning.

WiLliam MoskofF

Sangamon State University

TURKEY, THE STRAITS AND U.S. POLICY. By Harry N. Howard. Baltimore and London: The Johns Hopkins University Press, 1974. xiv, 337 pp. $\$ 14.50$.

The hero of this book is a treaty. The Montreux Convention, concluded in 1936, allowed Turkey to exercise sovereignty over the Straits (and thus to fortify them) and laid down detailed rules of passage for merchantmen and warships in time of peace and in time of war. Today, after a world war, three decades of continuing crisis in the eastern Mediterranean, and several revolutions in military technology, it remains in force. The Turks control the Straits and the Russians are playing the game according to the rules. Their past attempts to change the rules provide a main theme of this book. 